\title{
Women's Empowerment and the Resilience of Local Products: Technology-Based Regional Economic Development Models
}

\author{
I G A Purnamawati ${ }^{1}$ and N K S Adnyani \\ \{ayupurnama07@yahoo.com\} \\ ${ }^{1}$ Department of Accounting, Faculty of Economic, Universitas Pendidikan Ganesha, Indonesia \\ ${ }^{2}$ Department of Law, Faculty of Law and Social Science, Universitas Pendidikan Ganesha, Indonesia
}

\begin{abstract}
This study aims to have deeper examination on women's empowerment and the resilience of local products to strengthen the regional economy through technologybased development model. The sample of this study is MSMEs which has geographical indication products in Klungkung Regency, Bali. The results of the study are: the increase in the quality of human resources in the field of creative industries has a positive influence in terms of socio-economic community; improving the quality, quantity and distribution of welfare, technology-based production, empowerment, and patterns of cooperation between the community in Klungkung.
\end{abstract}

Keywords: Klungkung Regency, Bali, economy.

\section{Introduction}

The model of local economic reinforcement in this research is to move the role of endek women craftsman to be more bottomed up and managed independently by the group with the help of various related elements in the village, sub-district and district level. The main core is the participation of the women in which the representation of the community is a subject rather than an object. In a participatory economy, the community as one of the stakeholder elements of the region will be a major director in the wheel of economic activity in the region. Research by [1] about Creative Industries are the most influential economic source in the the recent years. They was stated: economic growth is very dependent on the discovery of new ideas, which then led to the concept of the economy which was originally based on manufacturing industry towards creative economy (intellectual as the main asset). The results of his research showed that the creative industry and innovation have a close relationship in the conceptual level, where they support each other for national economic growth in Indonesia.

The synergy model of the local economy reinforcement with the involvement of Balinese women in developing of small endek industries in Klungkung Regency basically builds institutional reinforcement synergy, the concept of synergizing the various mediums among sectorial institutions, the synergy between inter-regional actors, the synergy of the function and the type of institutional services of the economic people is applied (linked) to the characteristics of the economic activities of the community. Research by [2] shows that there is a strong and direct relationship between women's empowerment and economic 
development, namely the inequality of male and female roles driven by economic development. In addition, women's empowerment has a positive influence on development. Women are not seen as an integral part in terms of economic development policies and strategies. The high investment in terms of female reproduction compared to its productivity, resulting in women's involvement is very important in the development of the world economy as a whole. This has resulted in many projects failing because the main goal is welfare and not towards development which only offers side jobs for women in terms of jobs that have limited access such as knitting and sewing. Even today, several independent women's associations in India which are private organizations have carried out their roles effectively in improving the status and welfare of women who are the main capital in economic development.

The survey results of MSMEs business climate mapping in Klungkung district stated that $35 \%$ of micro and medium entrepreneurs have problems with market access, $25 \%$ have problems about improving the quality of workers in the business sector and $60 \%$ have problems with access to capital. It shows that there are still many problems faced by MSMEs, especially in building a good network that has been recorded in survey and that has not been recorded yet, a Survey conducted by GTZ Red (Regional Economic Development). Then become a strategic for KPPU who has given role of supervision of MSMEs and bigger company to avoid exploitation of MSMEs by big Company because of its weak bargaining position. Moreover, some Klungkung endek design product has not been registered as geographical indication product of Klungkung regency. This is certainly a very vulnerable occurrence claims. Geographical indications follow first to file system, registration is the main requirement to get protection. While the target is increasing knowledge and attitude of entrepreneur and increasing productivity of small business. Based on the results of the study in the first year (2017), the efficiency of the local economic reinforcement model for Balinese women in endek craft as a geographical indication product can be analyzed from the level of growth of SMEs with the Balinese women involvement on endek crafts in Klungkung District. It has been proven to be able to become "buffers" in the economy of the local community, because these conditions encourage community to initiate a movement, especially women, to undertake alternative economic activities in an effort to survive. This is proven in the quantitative growth in the number of SMEs in Indonesia (2017) which reached 40,137,773 million (99.86\%) of the total number of business operators which is 40,197.61 million, while micro-entrepreneurs reached $97.6 \%$ of the total small and medium enterprises [3]. This shows the very large contribution of SMEs to economic growth. According to BPS calculations with this number, SMEs are able to provide $99.04 \%$ of the national employment, the contribution to GDP reaches $63.11 \%$ and provides income of $14.20 \%$ outside of non-oil and gas.

The government has made various efforts in terms of fostering and developing small businesses, but this has not had a significant impact. This is proven by the growth of small business which is still far from expectations because it is always trapped in the classic and complex problems that are faced. While the internal problems are the quality of human resources, working capital, provision of raw materials, entrepreneurship, organization, and business management. From the external side, including the procurement of raw materials, access to finance or credit institutions, marketing, competition, bureaucracy, and economic policy support that has not been fully in favour of small business. Therefore, responding to the complexity of the problems experienced by SMEs, the research team in the first year (2017) has succeeded in drafting a model of local economic reinforcement and targeting the three basic dimensions of community empowerment, namely: (1) Core: Investment to increase community assets and capability poor, both as individuals and collective. Direction: Ability to solve problems independently and increase bargaining power in institutional relationships. (2) 
Support: Institutional reform towards good governance and public accountability, both due to community demands and due to the imperative of adjustment to the shift of development paradigm. (3) Mechanisms: Changing power relationships through a dialogical or interactive process towards a relationship based on equality, justice and dignity. From those three basic dimensions of community empowerment, especially the Balinese women, poverty alleviation must be comprehensive. Starting from the improvement of education and skills, the provision of job opportunities and striving to the preparation of support institutions.

Balinese women's active role can support the development of new entrepreneurs based on local economic development. The design of the model of local economic reinforcement for Balinese women on endek craft (Geographical Indication product of MSMEs Klungkung) can be the development of business partnership that includes synergy which is the implementation of Corporate Social Responsibility, that is kind of concern or moral responsibility from big companies to provide assistance to the community or small and medium enterprises in developing their business. As a manifestation of awareness and in an effort to encourage economic growth in realizing the welfare of the community, the government through the Decree of the Minister of SOE No. 236/2003 obliges SOEs to set aside 1-2\% of the company's net profit for PKKBL program, Partnership Credit Program and Community Development Program. Social justice problems is very closely related to gender equality by using approaches that are based on economic efficiency and rights. When the whole community plays a role, it will have the opportunity to get social justice, economic efficiency, economic growth and development. Respecting women's rights is the main thing in overcoming cultural, economic and social barriers. Especially in the relationship between sexual discrimination and other forms. For this reason, the need for various forms of policies and programs in dealing with discrimination against women. It is seen in various countries that the wage gap between men and women is clearly visible in the workplace. This is because women are more influenced by poverty and the type of work that is worth doing than men. This of course harms women and has a big impact on the economy. Increasing local productivity and demand and supply of goods and services can provide more employment for women and men through increased consumption [4]. The research's aim of [5] was to assess the influence of women's empowerment on socio economic development. They saw the AGASEKE Project as a case study. Access to the AGASEKE Project has resulted in several significant changes related to gender relations at the household level. The AGASEKE project has a significant effect in increasing the power of decision making by women. In addition, the level of domestic violence showed a decline after women's participation in the AGASEKE Project. Thus, the AGASEKE Project has a positive influence on improving women's basic needs, both at the household and community level. Overall, participation in the AGASEKE Project has contributed to the socio-economic development of women as project beneficiaries. Research by [6] carried out two aspects, namely empowerment and relationship development, where reciprocal relationships are so weak that sustainable policy commitments to gender equality may be needed to realize equality between men and women. Economic development and women's empowerment are significantly and unidirectionally related, where development does not only support inequality between men and women; but on the other hand women's empowerment has a positive impact on development. The result of the research conducted by [7] on gender and local economic development stated that Women's Empowerment means that women have the power to regulate daily activities in the external environment as in social, political and economic terms. Women's empowerment is a new expression in economic development. Many researchers have proven that increasing women's empowerment has undergone drastic changes in economic development. Empowering women and increasing 
gender equality is enshrined as a global development activity in the Millennium Development Goals (MDGs) in the 2000s. Women's institutions and freedoms are important tools to improve their development [2].

The local economic development model realized through the main program for the development of Small and Medium Enterprises can be seen through a process where development actors work together with partners from the public, private and non-government sectors in terms of realizing better economic growth and policies in terms of providing field work. Through this process, they formed and maintained a dynamic business climate, increasing economic prosperity and the quality of life for the entire community. Economic empowerment is the capacity of women and men to contribute and participate in the process of economic growth through recognition of values, mutual respect for the dignity of women and men, resulting in fair distribution and growth. Economic empowerment can increase access for women towards economic resources, employment opportunities, financial services, property, other productive assets, market information and competency development [8]. The main feature of local economic development is emphasizing on local-based development policies using local human resources, institutional and natural resource potentials forming regional competitiveness which are as follows: (1) Conducive business climate creation program. (2) Program for increasing access to productive resources. (3) Entrepreneurship and small business development programs are competitive. The goal is to develop entrepreneurial behaviour as well as to enhance the competitiveness of small business. The development program and its policies do not see women as part of the development process, especially if measured in terms of the high role of women in terms of reproduction compared to their productive role in terms of population. However, in reality, women play an important role in the economic process, especially in generating income. More women work in the informal and agricultural sectors, as well as jobs in the formal sector. Women's associations in India play an important role in improving the status of women in economic terms and their important role in the development process [9].

Reorganize the growth of local creative economic in the field of Klungkung endek woven handicraft which become the product of geographical indication is considered important for immediate review given the endek products on the market which many had claimed the motives that can harm endek craftsmen. SMEs as the craftsmen's supporter should respond well, as the impact on the sales of the declining products since consumers are promised sloping prices with craftsmen selling counterfeit products. Therefore, the model of local economic reinforcement is expected, the women craftsmen can coordinate with related institutions, in this case is Department of Industry and Commerce in Klungkung to immediately take care of the copyright of geographical indication product, so that it can be a guarantee for endek products to have an official permission. This research should be done now, by targeting the development of the female resource of endek craftsmen, it is the process by which members of an endek leveraging SMEs can improve their individual capacity and institutions to produce sustainable and equitable improvements in quality of life according to their own aspirations. In the context of institutional reinforcement of SMEs endek craftsmen, structural changes are required to local institutions to improve living standards, productivity, creativity, knowledge and skills as well as institutional capacity to survive and adapt to the social changes that surrounded it.

However, responding to market demand and the existence of a participatory performance demonstration by women craftsmen of endek in Klungkung have answered the concept of gender equality in managed handicrafts. (1) The occurrence of duplication cases of tied endek handicraft motive by irresponsible craftsmen can have an impact in threatening product of 
local wisdom in Klungkung. (2) The model of the local economy reinforcement with the empowerment of Balinese women as well as responding to the stigma that women are not only minimal but labour-intensive work is hoped to able to take responsibility as owner, as well as manager, and coordinate the workers in every MSMEs located in Klungkung. Based on the problems that occur in sustainability of handicraft management of tied woven endek with the involvement of women are needed to be supported to be productive to grow so that there is no misuse of the function of the main tasks by certain parties that can actually harm in a long period of time, especially motive claiming, blurred role of women and men because of the ties of tradition and culture, and the optimization of local potentials that need to be productive. Micro business' women owners have an important role in the economy. Women's empowerment is also community empowerment. Community welfare in the economy through empowering women is influenced by socio-cultural factors which consist of problems in accessing employment, gender inequality, and harassment that limits women from accessing and controlling economic assets [10].

\section{Methodology}

This research is a development research model with populist economic approach in local economy reinforcement model of tied woven endek craft in Klungkung Regency. The subjects involved in this research are Disperindag, Dinas Koperasi and MSMEs, as well as the stakeholders which includes non-Government Organizations represented by representatives of SME owners who also have capacity as producer, distributor, and consumer.

\section{Result and Discussion}

\subsection{Women's Empowerment Strategic Plan in Creative Industry Sector.}

The purpose of consensus is to manage group conflict. The actions are: (1) Determining the rules of the game in the group; (2) Arranging compromises into public policy form; (3) Arranging compromise and developing interests; and (4) Strengthening compromises. The focus of the Local Economy Strengthening Model for Bali Women in Endek Craft (Geographical Indication Product) is targeting gender equality, protection of geographical indication, mutual cooperation between industry investors, policy and public sector penetration and effectiveness of local market reinforcement model to endek craft regardless of the participation of Balinese women in the highly participatory in Klungkung.

In accordance to the research conducted by [11], which examined the effect of participatory development programs implemented by the government on women's social and economic empowerment and their impact on poverty alleviation in the Nasirabad area of Balochistan (a province in Pakistan). The results of the study indicate an increase in indicators in quantitative measures namely capacity building, access to micro credit, involvement in economic activities and reduction of workload. So this reveals a paradoxical situation by beneficiaries if it is related to its role in economic activity, expenditure, and income. Reducing the workload of women is the main indicator in developing gender through evaluation of 
workload. [12] whom analyzes the existence of women in micro-enterprises and socioeconomic empowerment in Azad Kashmir. The socio-economic empowerment of women in micro-enterprises is a predictor variable. Economic freedom, and social improvement are the criteria. The results of the study revealed that after running a business, women were able to get socio-economic empowerment.

Table 1. Pattern of MSMEs

\begin{tabular}{lll}
\hline No & Pattern & Capacity \\
\hline 1 & $\begin{array}{l}\text { MSMEs with family } \\
\text { management patterns }\end{array}$ & $\begin{array}{l}\text { i.e. owned, controlled and run by members } \\
\text { of a family or managed by members of their } \\
\text { family }\end{array}$ \\
\hline 2 & $\begin{array}{l}\text { Family In-Company } \\
\text { Participation }\end{array}$ & $\begin{array}{l}\text { Can strengthen the company, because family } \\
\text { members are usually very loyal and highly } \\
\text { dedicated to their family company }\end{array}$ \\
\hline 3 & $\begin{array}{l}\text { Long-term orientation } \\
\text { towards business }\end{array}$ & $\begin{array}{l}\text { Considered as business continuity directly } \\
\text { related to family survival }\end{array}$ \\
\hline 4 & $\begin{array}{l}\text { From the side of of } \\
\text { corporate culture }\end{array}$ & $\begin{array}{l}\text { The family spirit determines the values, } \\
\text { norms and attitudes that apply in the } \\
\text { company }\end{array}$ \\
\hline
\end{tabular}

The results of this study can contribute: (1) Practically, the results of this research as recommendation materials to the authorities, such as Bank Indonesia, Commercial Bank, and Local Government (Regency or Province especially the Department of Industry and Trade, as well as Cooperatives and SMEs) in order to empower SMEs in each district through the development of a model of local economic reinforcement "MSMEs". (2) Theoretically, the results of this study as a reference for interested parties, such as students, academics, and investors, can help them understand deeper about the commodity business (product or type of endek) as the leading sector of SMEs in Klungkung in particular and in Bali in general. The findings in this research are: the strong influence of Purusa system in Balinese society also influence the performance of women who work in the field of art or craft, there is still assumption that woman is less suitable working in the field of crafts.

\subsection{Multiplier Effect generated by Local Products on Regional Revenues and Economic Resilience.}

The competitiveness of a region in Klungkung Regency is also strongly influenced by the creative industry factors of endek weaving developed by Balinese women, especially in MSMEs. The selection of commodities in determining competitiveness is crucial, considering that what determines competitiveness is a commodity. In other words, how the commodity is able to maintain the economic position of a region and Klungkung has endek handicraft products as a superior commodity which is a geographical indication product of Klungkung Regency. Regional income can stimulate the need for local and broader demand and endek Klungkung products (multiplier effects). Klungkung's development strategy based on industrial clusters allows the government to get the direct resources more effectively and efficiently. The clustering approach of the centralized industrial center by producing the role of Balinese women in endek woven craft MSMEs sector enables local governments to work directly with industries and develop strategies in a sustainable economy. This strategy 
provides a framework for the local government of Klungkung Regency in providing services for the entire cluster to provide maximum impact.

The existence of formal and informal institutions such as MSMEs is one of the capital that must be formed in local economic development activities. This institution will later become a media of choice when economic problems cannot be solved by market mechanisms anymore. Formal and informal institutions that are formed can complete transaction-based economic activities into a relationship that is based on community beliefs and norms. The availability of craftsman cooperatives also needs to be considered. Aside from being a support for Department of Industry and Commerce to facilitate training and assistance in improving the skills of Balinese women in the management of MSMEs, Klungkung endek handicrafts can be used as a means of learning and community empowerment regarding matters that support local economic development activities. Then there is an artisan organization which is incorporated as an exporter which is also a supporting indicator of good MSMEs. This institution can represent the voice and inspiration of the community in determining programs and decision-making processes in local economic development activities.

\subsection{Impact of the development of information and technology on improving the quality and quantity of local products.}

The era of information and technology that is developing increasingly proves that mastering good technology will have an impact on the quality and quantity of development itself. In order for technology to be well controlled by MSMEs managers, human resources are needed, namely Balinese women as quality craftsmen. In the context of the production process, the existence of good technology mastery will encourage technological innovation. These technological innovations can ultimately create new products and more efficient production methods that will facilitate the production process. So, in its implementation, quality human resources are needed in the achievement of local economic development. Existing human resources, apart from being a production force are also expected to be able to create high-value products by utilizing existing technology. The sustainability of local economic development is strongly influenced by the quality of its human resources by intensely participating in training and mentoring in increasing production, management, cooperation and licensing capacity developed for MSMEs in Klungkung.

In the process of development and economic growth, technological advances by most economists are considered the most important sources and are the determinants of success. Mastery of technology is how production factors are combined to realize production objectives. By using sophisticated technological capabilities, it is expected to make an innovation for a product to provide greater input. Technology in developed countries today is intensive capital that requires large capital. On the other hand, in developing countries, there is also a need for more labour, especially those who with good education or well educated. Utilization of technology and the transfer of functions has been carried out by Balinese women who are incorporated in a number of MSMEs in Klungkung District facilitated by academics and practitioners at the local government level. The production of Endek is a source of income and contributes well to the economy in Klungkung Regency. The realization target of the growth rate of craftsmen in Klungkung's Endek MSME is $6.29 \%$ and has been realized at $5.4 \%$ can be said to have relatively high achievement in 2018. Data on the economic growth of the handicraft sector in Klungkung shows that within one year, endek production increases. The increase of endek woven production capacity and the high contribution to the economy in Klungkung Regency are not matched with the welfare of craftsmen who are dominated by 
women. This is because endek craftsmen are only able to sell their products in the form of sheet cloth, in addition to the lack of information and marketing networks for craftsmen forcing craftsmen to sell by wholesale.

In addition, not many people are able to turn sheet cloth products into fashion variants and accessories that reflect high-value products and produce added value. Seeing the potential of endek woven that is able to contribute to the economy, it is necessary to innovate the production of endek sheet woven to be able to create competitiveness and provide added value to the community. So, the potential for endek woven crafts not only benefits the region, but can improve the welfare of the community as well. The innovations that are created are expected to be carried out on an ongoing basis, given the economic competition continues to run and develop. While there have not been many studies discussing the economic role of endek woven craft sectors involving Balinese women, this is important to determine the differentiation of endek woven handicraft products. Therefore, this study aims to formulate a model for the local economy reinforcement of Balinese women in endek woven craft to improve the economy and welfare of the community, especially the endek woven craftsmen in Klungkung Regency.

Capacity Building and Technology-Based Production

Expansion of national and international markets: Contribution will be given to each subsector

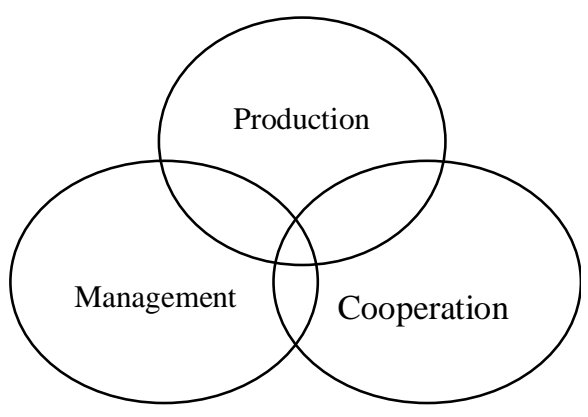

MSMEs that are competitive and sustainable: provision of inputs, cultivation of raw materials (threads, and natural coloring), process technology, marketing and infrastructure and supporting institutions (government, cooperatives, MSMEs, and the public, private entrepreneurs and business entities)

Fig. 1. Models of Women's Empowerment and Resilience of Local Products

Department of Industry and Commerce, Universities, Cooperatives and MSMEs provide marketing facilities in the form of exhibitions held at the District, National and Provincial levels. The exhibition, which was followed by international handicrafts products at the Gema Santhi festival, Disperindag, often brought woven crafts together with the Department of Industry and Commerce of Central Java and SMEs Office to be brought to Solo to be promoted. The form of partnership cooperation between MSMEs and related parties with aims to provide easy access for the center of the brass handicraft industry to obtain credit from rural banks through people's business credit program with an interest rate of $4 \%$ in a year. Endek woven handicraft entrepreneurs also get facilitation of capital access through socialization that is often held by Disperindag by presenting speakers from banks such as Bank Rakyat Indonesia and Bank Perkreditan Rakyat. The benefits of facilitating capital access are also felt by entrepreneur of endek woven craft because it can help to overcome capital problems so that it can help to continue their business.

Partnership cooperation between parties is important in developing the center of Klungkung's endek woven handicraft industry by involving the role of the women in the form 
of human resource development activities, marketing facilities, facilitation of capital access and information for SMEs aiming to develop endek woven industry centre. With the development of endek woven craft industry business, it has been able to create new jobs and provide business opportunities to foster new entrepreneurs.

In this globalization era, it is better to make a company that can survive in a prolonged economic crisis rather than a company that only rely on other company's finances. Because in addition to funding, the company has other resources that are not less important than human resources. A company in order to maintain its competitiveness, should consider two important factors namely personnel, human resources and technology. Human resource is a very important element in one company. Failure to manage human resources can lead to disruptions in the achievement of objectives within the organization, both in performance, profit, and the survival of the organization itself. The current general condition shows that the company is still weak in some ways, such as: inefficient management, limited funds and technology and inadequate quality of human resources. By looking at this reality, then in the business, the company must be able to analyze the quality of human resource management in order to improve the performance of the company that can be seen from the perspective of finance, customer perspective, internal business perspective, and learning and growth perspective. This study only discusses the factors of human resources management that affect the improvement of employee and company performance. One of the big problems for companies is to find professional and skilled human resources in an instant time, both in terms of technology and in managerial terms. If these human resource issues are neglected, then this will negatively impact the company's productivity, efficiency and competitiveness. Therefore, one of the company's goals and strategies is to develop technological, managerial, and professionalism capabilities of human resources, as well as increasing the productivity by increasing valueadded contents of products or faster services than competitors.

At this time the construction sector began to realize the importance of human resource management to improve the performance of the company, but still have to face many difficulties in the implementation of management and human resources development. There are several things that are the cause of the difficulty. First, the average education level of the workers compared to other sectors. Second, the unstable amount of labour used due to the changing of labour's needs. Third, there are subjective and objective reasons that limit workers' participation. Subjective reasons are the characteristics of production procedures, materials, and technologies that do not provide many opportunities for workers to make decisions. An objective reason is the management's view that machines and manuals of work are more important than workers. Fourth, the widely applied subcontracting system in the construction industry has caused no party to take responsibility for training and development of workers[13][14].

Small businesses still survive in the structure of the economy and even government policies on the existence of small businesses are increasingly conducive and positive. The results of several previous studies say that small businesses have a complementary role with large companies in job creation and economic growth. Thus, the development of the MSME sector in the tourism industry is caused by innovations in the hotel sector and travel agents. Micro-businesses are small-scale businesses run by direct owners and grow from communities that have low income in terms of providing services and products as well as a combination of both. There are several businesses that carry out their activities under the auspices of dynamic supervision with location and financial challenges. These businesses strive to meet market needs with the aim of obtaining financial benefits for business expansion. 


\section{Conclussion}

The existence of SMEs has not only contributed significantly to Gross Domestic Product and employment, but it has to be recognized that MSMEs have played a very important role as a safety valve for the national economy during the crisis. This happened once in Indonesia when the monetary crisis hit which later developed into a multi-dimensional crisis. It happened when large business are still caught up with the problem of dependence on foreign loans that are increasingly bloated due to the crisis. However, SMEs that are flexible in business development actually not affected by this monetary crisis, especially for SMEs that are engaged in business oriented to foreign markets (exports). When the crisis happened, these SMEs were leading the Indonesian economy. Meanwhile, [13] said that small businesses are also able to reduce income inequality, especially in developing countries, while [14] confirmed that small businesses contribute greatly to the provision of employment. So the role of small-scale companies in Indonesia can be said to be very important in facing the country's economic resilience. This study aims to prove the influence of internal, external, entrepreneurial skills, strategies and performance on the competitiveness of MSMEs partially or simultaneously where factors can explain their role as organizational environmental factors that can be distinguished on internal and external environments.

\section{References}

[1] A. R. T. Hidayat and A. Y. Asmara, "Creative industry in supporting economy growth in Indonesia: Perspective of regional innovation system," in Earth and Environmental Science 70, 2017 , pp. $1-10$.

[2] S. D. Bhoganadam, H. Malini, and D. S. Rao, "Women Empowerment and Economic Development," Int. J. Multidiscip. Manag. Stud., vol. 4, no. 8, pp. 100-107, 2014.

[3] Badan Pusat Statistik, "Statistik Indonesia 2015," Jakarta, 2015.

[4] International Labour Bureau for Gender Equality, "Gender Mainstreaming in Local Economic Development Strategies," Geneva, Switzerland, 2010.

[5] U. K. Liliane and P. Mbabazi, "The Impact Of Women Economic Empowerment Projects On Their Socio-Economic Development In Rwanda: The Case Of Agaseke Project," Eur. J. Bus. Soc. Sci., vol. 4, no. 6, pp. 59-87, 2015.

[6] E. Duflo, "Women Empowerment and Economic Development," J. Econ. Lit., vol. 50, no. 4, pp. 1051-1079, 2012.

[7] I. Bruegel, "Gender and Local Economic Development," Local Econ., vol. 15, no. 1, pp. 2-8, 2010.

[8] R. Eyben, N. Kabeer, and A. Cornwall, "Conceptualising empowerment and the implications for pro poor growth," 2008

[9] R. Mehra, "Women, Empowerment, and Economic Development," Ann. Am. Acad. Pol. Soc. Sci., vol. 554, no. 1, pp. 136-149, 1997.

[10] M. C. Wube, "Factors Affecting The Performance Of Women Entrepreneurs In Micro And Small Enterprises (The Case Of Dessie Town)," Bahir Dar University, 2010.

[11] A. R. Khan and Z. Bibi, "Women's Socio-Economic Empowerment Through Participatory Approach: A Critical Assessment," Pak. Econ. Soc. Rev., vol. 49, no. 1, pp. 133-148, 2011.

[12] S. Akram, I. Shaheen, and S. M. Kiyyani, "Socio-Economic Empowerment Of Women Through Micro Enterprises: A Case Study Of AJK,” Eur. Sci. J., vol. 11, no. 22, pp. 197-211, 2015.

[13] H. El-Gohary, "E-Marketing - A literature Review from a Small Busi nesses perspective," Int. J. Bus. Soc. Sci., vol. 1, no. 1, pp. 214-244, 2010. 
[14] S. J. Appold, S. Siengthai, and J. D. Kasarda, "The Employment of Women Managers and Professionals in an Emerging Economy: Gender Inequality as an Organizational Practice," Adm. Sci. Q., vol. 43, no. 3, pp. 538-565, 1998. 